\title{
Beyond the bolus: transgenic tools for investigating the neurophysiology of learning and memory
}

\author{
Christine Lykken ${ }^{1}$ and Clifford G. Kentros ${ }^{1,2}$ \\ ${ }^{1}$ Department of Biology, Institute of Neuroscience, University of Oregon, Eugene, Oregon 97403, USA; ${ }^{2}$ Kavli Institute \\ of Systems Neuroscience, NTNU, 7030 Trondheim, Norway
}

\begin{abstract}
Understanding the neural mechanisms underlying learning and memory in the entorhinal-hippocampal circuit is a central challenge of systems neuroscience. For more than $\mathbf{4 0}$ years, electrophysiological recordings in awake, behaving animals have been used to relate the receptive fields of neurons in this circuit to learning and memory. However, the vast majority of such studies are purely observational, as electrical, surgical, and pharmacological circuit manipulations are both challenging and relatively coarse, being unable to distinguish between specific classes of neurons. Recent advances in molecular genetic tools can overcome many of these limitations, enabling unprecedented control over neural activity in behaving animals. Expression of pharmaco- or optogenetic transgenes in cell-type-specific "driver" lines provides unparalleled anatomical and cell-type specificity, especially when delivered by viral complementation. Pharmacogenetic transgenes are specially designed neurotransmitter receptors exclusively activated by otherwise inactive synthetic ligands and have kinetics similar to traditional pharmacology. Optogenetic transgenes use light to control the membrane potential, and thereby operate at the millisecond timescale. Thus, activation of pharmacogenetic transgenes in specific neuronal cell types while recording from other parts of the circuit allows investigation of the role of those neurons in the steady state, whereas optogenetic transgenes allow one to determine the immediate network response.
\end{abstract}

Electrophysiological recordings have been used to study "receptive fields" (RFs) (Table 1) throughout the brain for more than 50 years. Hubel and Wiesel (1959) were among the first to characterize RFs in the brain by recording in the cat striate cortex from neurons that fired specifically in response to bars or edges of specific orientations. This led them to propose that the orientationselective RFs of striate neurons originate via linear summation of aligned RFs of lateral geniculate neurons (Hubel and Wiesel 1962). Unfortunately, the predictions of this model were largely untestable because electrophysiological recordings are purely observational. Although Chapman et al. (1991) were able to provide evidence consistent with Hubel and Wiesel's model by using clever electrophysiological techniques, they were even unable to directly confirm the model. Therefore, determining how the RFs of upstream neurons generate the RFs of downstream neurons remains a central goal of systems neuroscience. Excitingly, recent advances in molecular genetic techniques potentially enable empirical testing of purely theoretical models.

Given the centrality of the entorhinal cortex and hippocampal formation to memory (Scoville and Milner 1957), this review focuses on the RFs of neurons in this circuit. More than 10 years after the seminal work of Hubel and Wiesel, O'Keefe and Dostrovsky (1971) reported their discovery of cells with spatial RFs in the hippocampus. These "place cells" fired whenever the rat was in a specific location in the environment, referred to as the cell's "place field" (Fig. 1A). Following the discovery of place cells in the hippocampus, electrophysiological recordings have traditionally been used to characterize the firing properties of place cells and other spatially responsive cells in the entorhinal-hippocampal circuit. In 2005, Hafting et al. described the spatial organization of the firing fields of "grid cells" in the superficial layers of the medial entorhinal cortex (MEC), which form a periodic triangular array tiling the entire environment (Fig. 1B). Head direction

Corresponding author: cleef@uoregon.edu

Article is online at http://www.learnmem.org/cgi/doi/10.1101//m.036152.114. cells in MEC and post-subiculum (among other regions) encode the animal's head direction with respect to the environment, regardless of the animal's location or behavior (Fig. 1C; Ranck 1985; Taube et al. 1990a,b; Sargolini et al. 2006). Border (or boundary vector) cells in the MEC, parasubiculum, and subiculum fire near borders of the local environment (Fig. 1D; Savelli et al. 2008; Solstad et al. 2008; Lever et al. 2009).

Just as recordings of striate neurons led to models suggesting that the RFs of upstream neurons could combine to form the RFs of striate cells, the discovery of grid cells led to several theoretical models proposing that grid cell inputs could be combined to generate place cells (Fuhs and Touretzky 2006; McNaughton et al. 2006; Rolls et al. 2006; Solstad et al. 2006; de Almeida et al. 2009; Si and Treves 2009; Savelli and Knierim 2010; Monaco and Abbott 2011). Empirical evidence demonstrating that the removal of CA3 input to CA1 (leaving direct entorhinal input intact) does not eliminate place cell responses supports this hypothesis as well (although CA2 or extrahippocampal input may also contribute) (Brun et al. 2002; Nakashiba et al. 2008). However, recent research indicates that eliminating the spatial firing pattern of grid cells by pharmacologically inactivating the medial septum has little effect on the maintenance and formation of place fields in familiar and novel environments, respectively (Koenig et al. 2011; Brandon et al. 2014). These and other recent empirical findings (Mizuseki et al. 2009; Langston et al. 2010; Wills et al. 2010; Barry et al. 2012; Neunuebel et al. 2013; Neunuebel and Knierim 2014) challenge the idea of a simple grid to place cell transformation. Alternative network models developed prior to the discovery of grid cells suggest that the network exhibits place selective activity as a consequence of stable

(C) 2014 Lykken and Kentros This article is distributed exclusively by Cold Spring Harbor Laboratory Press for the first 12 months after the full-issue publication date (see http://learnmem.cshlp.org/site/misc/terms.xhtml). After 12 months, it is available under a Creative Commons License (AttributionNonCommercial 4.0 International), as described at http://creativecommons. org/licenses/by-nc/4.0/. 
Table 1. Key terms

\begin{tabular}{ll}
\hline Term & \multicolumn{1}{c}{ Definition } \\
\hline Receptive field & The portion of sensory space to which a \\
neuron responds. & The specificity of a virus for a particular host \\
tissue. & The protein coat of a virus particle that \\
Capsid & Surrounds the genetic material. \\
Virions & (1) genetic material (DNA or RNA), (2) \\
protein coat, and (3) lipid envelope \\
surrounding protein coat (in some cases). \\
An enveloped virus particle assembled with \\
a foreign viral glycoprotein. These viruses \\
infect different cells than the wild-type \\
virus does. The cell type is determined by \\
the foreign glycoprotein. \\
Small circles of double-stranded DNA that \\
can replicate in bacterial cells \\
independently of the bacterial \\
chromosome. Carrying capacity $\sim 15$ kb. \\
Recombinant DNA molecules formed by \\
combining chromosomal replication and \\
segregation elements with a DNA insert. \\
Carrying capacity $\sim 300$ kb. \\
Chromatin states that differ in the degree of \\
compaction, the location of neighboring \\
genes, and the presence/absence of \\
cis-regulatory elements, which may affect \\
the accessibility of transcription factors to \\
their DNA binding sites. \\
Regions of noncoding DNA that regulate \\
transcription of nearby genes. Often \\
contains binding sites for transcription \\
factors including enhancers, repressors, \\
and insulators that regulate gene activity \\
far away from the transcription start site \\
and can act over long distances. \\
Chromatin context
\end{tabular}

Definitions of related terms.

attractor states (Samsonovich and McNaughton 1997; Tsodyks 1999). Others propose that place cell firing is primarily driven by input from other spatially responsive neurons in the entorhinal cortex, such as border/boundary vector cells (O'Keefe and Burgess 1996; Hartley et al. 2000; Barry et al. 2006; Bush et al. 2014). In contrast, Kropff and Treves (2008) suggest that the combination of feedforward cortical afferents and feedback hippocampal projections from place cells generates grid cells. Finally, oscillatory interference models indicate that RFs of spatially responsive neurons result from phase interference among theta oscillations with frequencies that are modulated by the speed and direction of translational movements (Burgess et al. 2007). Empirical studies reporting modulation of theta frequency by movement speed and direction provide support for this model (Rivas et al. 1996; Geisler et al. 2007; Jeewajee et al. 2008; Welday et al. 2011).

Unfortunately, these competing computational models are largely untestable using observational electrophysiological studies alone. Although extracellular recordings have high temporal resolution, they lack cell-type specificity due to the difficulty in distinguishing between diverse classes of neurons. Recording site identification relies upon path reconstruction of the electrode track, which resolves cell layer at best. In addition, circuit manipulations during in vivo recordings suffer from serious limitations, complicating our ability to generate empirical evidence in support of these models. Existing manipulations involve surgical lesions, injections of pharmacological agents, or electrical stimulation, which are regional rather than cell-type specific. Electrical and pharmacological manipulations involve either a current point source or the injection of a bolus of substance, which result in strong effects at the injection site that decay unpredictably both spatially and temporally. Even pharmacological manipulations that preferentially degrade grid cell firing involve local injections of diffusible substances and interfere with cholinergic modulation throughout the forebrain (Brandon et al. 2011, 2014; Koenig et al. 2011). Traditional circuit manipulations simply do not operate at the same level of granularity as the neural circuits that underlie behavior. Therefore, the future of systems neurophysiology involves getting "beyond the bolus." The combination of celltype-specific transgene expression, electrophysiological recordings, and recently developed molecular tools holds the promise of achieving this ambitious goal, allowing the cell-specific investigation of the anatomy and physiology of the entorhinal-hippocampal circuit.

This review details recent advances in pharmaco- and optogenetics that can be used in conjunction with cell-type-specific transgene expression and electrophysiology to investigate both steady-state and acute network responses to manipulate neural activity within the entorhinal-hippocampal circuit. We first review genetic expression systems, which can be used to target a transgene to neural cell types of interest. We pay special attention to binary systems in which a "driver" line produces cell-type-specific expression of a "payload" transgene delivered via viral injection or by crossing with a sec transgenic line. Next, we describe both early approaches and recent developments in pharmacogenetics, or the use of designer receptors to pharmacologically modulate steady-state neural function. Finally, we discuss the development of a variety of optogenetic transgenes, which enable light-dependent excitation or inhibition on a millisecond timescale.

\section{Genetic expression systems}

Although Hubel and Wiesel (1962) understood the basic anatomy and RF structure in the visual circuit, the predictions of their model
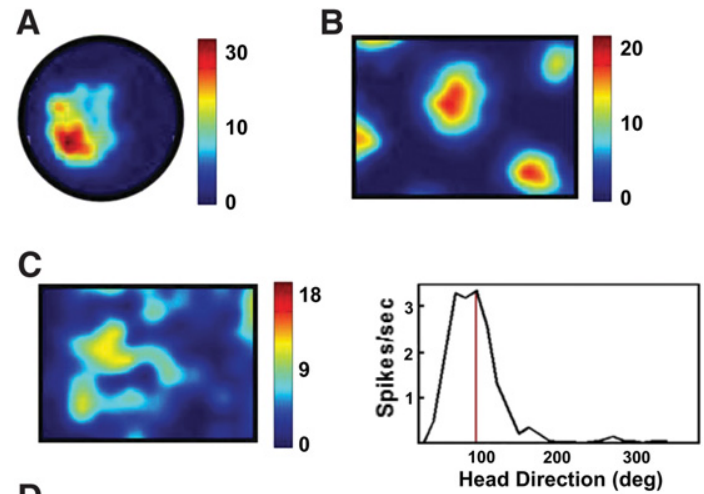

D

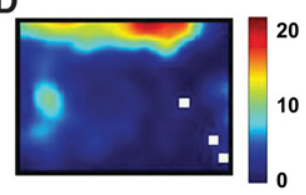

Figure 1. Cells with spatial RFs in the entorhinal-hippocampal circuit. $(A)$ Color-coded rate map for hippocampal place cell. $(B)$ Color-coded rate map for grid cell in medial entorhinal cortex (MEC) LII. (C) (Left) Color-coded rate map for head direction cell in MEC LII. (Right) Head direction tuning curve for head direction cell. $(D)$ Color-coded rate map for border cell in MEC LII. In each panel, the firing rate color scale is shown to the right of each rate map. Firing rate is measured in Hertz. Red is maximum, dark blue is zero. White pixels represent unvisited locations. 
were largely untestable using observational electrophysiological recordings alone. In order to gain a more complete understanding of the structure and function of a neural circuit, it is necessary to determine patterns of connectivity between cell types and to perform cell-type-specific circuit manipulations. To achieve these goals, a variety of strategies have been developed to insert transgenes into a neural subpopulation of interest. Here, we review viral (Fig. 2A), transgenic (Fig. 2B), and combinatorial systems (Fig. 2C) for obtaining transgene expression.

\section{Viral transduction of transgenes}

A wide variety of viral vectors can be used to express transgenes in neurons (Table 2; for a complete review of viral vectors, see Walther and Stein 2000; Davidson and Breakefield 2003; Zhang et al. 2010). The specificity of a virus for a particular host tissue (its "tropism") is determined by the interaction of viral coat proteins and cell-surface receptors in the host tissue. One of the most commonly used viral vectors, adeno-associated virus (AAV), has a simple coat protein that exists in more than 100 different variants. Several different serotypes of $\operatorname{AAV}(1,2,5,8$, and 9) have been shown to transduce neurons in the brain, each with slightly different tropisms and transduction efficiency (Zhang et al. 2010). In contrast, lentivirus (LV), another widely used viral vector, has enveloped "virions" in which the "capsid" is surrounded by a lipid bilayer envelope. Enveloped viruses can be "pseudotyped" with foreign coat proteins, facilitating a greater degree of cell-type-specific expression because the virus will preferentially infect cells with receptors for its coat protein. Although both AAVs and LVs are highly effective for gene delivery, transgene expression driven by cell-type-specific promoters is difficult due to the limited packaging capacity of these vectors ( $\sim 5$ and $\sim 8 \mathrm{~kb}$, respectively) (Davidson and Breakefield 2003). This size limitation prevents the expression of large promoter sequences that can provide increased specificity. In contrast, other viral vectors such as herpes simplex virus (HSV) have a much larger packaging capacity $(\sim 150 \mathrm{~kb})$, enabling targeting of specific cell populations (Zhang et al. 2010). Unfortunately, due to its larger genome, HSV is more difficult to manipulate than viruses with small genomes.

\section{Anterograde and retrograde labeling}

Transduction of viral vectors enables both anterograde and retrograde tracing capabilities. Although retrograde transport of lentiviral vectors is limited, lentivirus-based expression of enhanced green fluorescent protein (GFP) has been used as a high-resolution axonal tracing method (Grinevich et al. 2005). Recombinant AAV (rAAV) has been used both as an anterograde and a retrograde tracer in order to map axonal projections (Chamberlin et al. 1998; Harris et al. 2012; Zhang et al. 2013). Furthermore, HSV, canine adenovirus type 2 (CAV-2), rabies virus, and pseudorabies virus undergo robust retrograde transport and can be used to target specific populations of neurons (Soudais et al. 2001; Zhang et al. 2010). Of these, only rabies virus undergoes robust transsynaptic transport that is exclusively retrograde. In a particularly interesting recent development, Wickersham et al. (2007) replaced the glycoprotein gene of recombinant rabies virus with a fluorophore pseudotyped with the avian viral coat protein EnvA. This resulted in the in vitro infection of neurons containing the EnvA receptor TVA, as well as monosynaptic spread of rabies virus from the original infection site. Subsequently, our laboratory developed a transgenic mouse line to deliver the rabies glycoprotein and the TVA receptor in a cell-type-specific manner, facilitating directed in vivo infection of recombinant rabies virus with transport restricted to a single synapse (Weible et al. 2010). By combining cell-type-specific infection, monosynaptic retrograde transport,
A

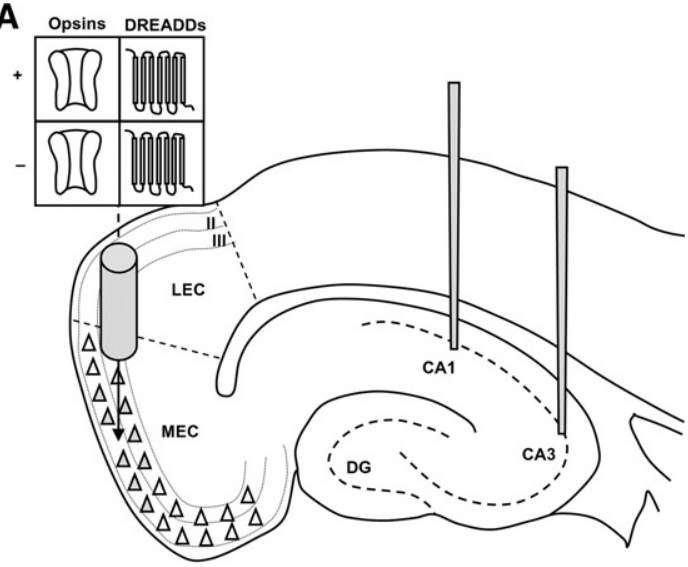

B

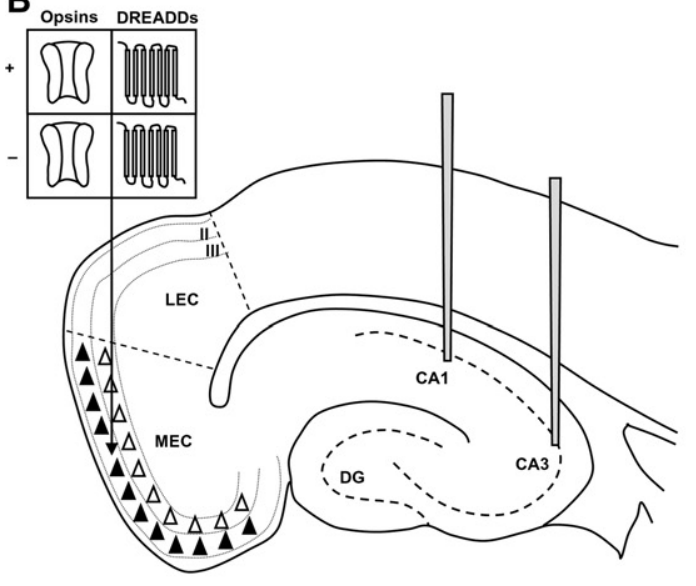

C

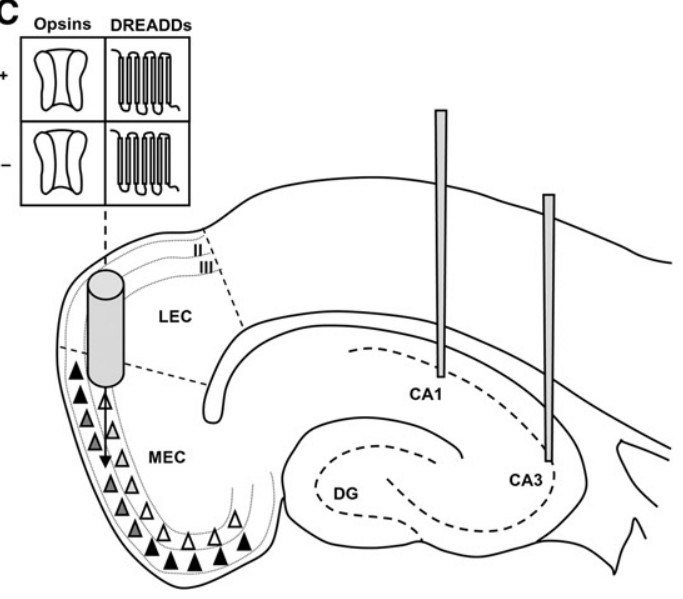

Figure 2. Viral $(A)$, transgenic $(B)$, and combinatorial $(C)$ expression of optogenetic or pharmacogenetic transgenes in MEC LII for activation or inhibition of neural activity. Electrodes in downstream hippocampal subregions CA1 and CA3 (gray) record acute or steady-state network responses to optogenetic or pharmacogenetic manipulations, respectively. Each panel shows a horizontal section through the left hemisphere of a rat brain focusing on the entorhinal-hippocampal circuit. White triangles represent uninfected cells. $(A)$ Light gray triangles represent noncell-typespecific viral expression of transgene in MEC LII and LIII. (B) Black triangles represent dispersed, cell-type-specific transgenic expression in MEC LII. (C) Black triangles represent cell-type-specific transgenic expression of "driver" (i.e., Cre, Flp, tTA, etc.). Light gray triangles represent noncelltype-specific viral expression of transgene. Medium gray triangles represent combination of transgenic expression of "driver" and virally mediated expression of "payload" transgene which offers increased anatomical specificity. 
Table 2. Viral vectors

\begin{tabular}{|c|c|c|c|c|c|c|c|}
\hline Vector & Type & Particle size & Titers & Capacity & $\begin{array}{l}\text { Virion } \\
\text { type }\end{array}$ & Onset & Duration \\
\hline AAV & ssDNA & $20-30 \mathrm{~nm}$ & $10^{9}-10^{13}$ & $\sim 5 \mathrm{~kb}$ & Capsid & Weeks & Years \\
\hline Advantages & \multicolumn{7}{|c|}{$\begin{array}{l}\text { Safe (BSL-1), nontoxic } \\
\text { Easy to obtain or produce } \\
\text { Can increase expression level by increasing co } \\
\text { Coat protein can be pseudotyped, enabling a } \\
\text { Good penetration due to simple coat protein } \\
\text { Can be used for anterograde or retrograde del } \\
\text { Limited packaging capacity } \\
\text { Variable levels of opsin expression across cells } \\
\text { Does not integrate into host genome }\end{array}$} \\
\hline Lentivirus & RNA & $100 \mathrm{~nm}$ & $10^{6}-10^{9}$ & $\sim 8 \mathrm{~kb}$ & Envelope & Weeks & Years \\
\hline Advantages & \multicolumn{7}{|c|}{$\begin{array}{l}\text { Nontoxic } \\
\text { Easy to obtain or produce } \\
\text { Can increase expression level by increasing copy number } \\
\text { Coat protein can be pseudotyped, enabling a range of tropisms } \\
\text { Integrates into host genome }\end{array}$} \\
\hline Rabies virus & RNA & $180 \mathrm{~nm}$ & $10^{8}$ & $\sim 5 \mathrm{~kb}$ & Envelope & Days & $\begin{array}{c}\text { Toxicity at } \\
\sim 10 \mathrm{~d}\end{array}$ \\
\hline Advantages & \multicolumn{7}{|c|}{$\begin{array}{l}\text { Undergoes monosynaptic retrograde transport } \\
\text { Possible to pseudotype glycoprotein coat } \\
\text { Can express a variety of payloads (GCaMP3, ChR2, CreER, Flp) }\end{array}$} \\
\hline HSV-1 & dsDNA & $120-300 \mathrm{~nm}$ & $10^{12}$ & $\sim 30-50 \mathrm{~kb}$ & Envelope & Weeks & Months \\
\hline Advantages & \multicolumn{7}{|c|}{$\begin{array}{l}\text { Undergoes retrograde transport } \\
\text { Large packaging capacity } \\
\text { HSV-1 can be engineered for reduced toxicity }\end{array}$} \\
\hline
\end{tabular}

For a complete review of viral vectors, see Walther and Stein (2000); Davidson and Breakefield (2003) and Zhang et al. (2010).

Expression onset, direction, and specificity may vary with organism and brain region.

of virus, resulting in incomplete coverage of target neurons or superfluous transduction of surrounding neurons. Virus injections are also invasive, and it is difficult to precisely target viral injections across animals. Furthermore, viral transduction with certain viral vectors may result in differential transgene expression across cells or animals. The amount of virus can differ even across neighboring cells in a titer-dependent fashion due to the number of viral genomes per cell and also due to the insertional effects of LVs (see next section). Finally, all viruses can be cytotoxic to varying degrees, and the same can be said for the transgenic payloads they express, especially at extremely high levels. Thus, although viruses are easy to use, they lack cell-type specificity and expression patterns often vary between experiments.

\section{Genomic insertion of transgene}

To overcome these limitations, genomic insertion of transgenes can be used to obtain dispersed, reproducible, and stable patterns of transgene expression in defined neural populations (Fig. 2B). Within this section, we will describe several techniques for genomic insertion of transgenes, including random insertion, targeted insertion, and binary systems based on site-specific DNA recombination or transactivation.

\section{Random insertion}

Random insertion of a transgene involves the insertion of exogenous genes to a host genome using a minimal promoter/enhancer added to a "plasmid"

and unambiguous label, this approach enables the determination of the connectivity of the mammalian brain with cellular-level resolution. In fact, our laboratory used this transgenically targeted viral tracing method to identify the monosynaptic inputs to the projection neurons of layer II of the MEC in mice (Rowland et al. 2013). In addition to confirming prior anatomical work, the results revealed a novel major direct input to MEC LII from area CA2, a region previously considered to be simply a transitional zone between CA3 and CA1.

\section{Advantages and disadvantages of viral transduction}

Although a limited degree of preference for cell type can be achieved via viral transduction, the advantages of viral vectors are primarily related to their ease of generation. It is far less time consuming to produce virus than to generate a novel transgenic line (weeks versus months). The most commonly used viral vectors, AAVs and LVs, are versatile, easy to produce or obtain, and are relatively nontoxic. The onset of expression with these viruses is generally within 1-2 wk and expression often lasts for years. Despite its ease of use, viral transduction suffers from several limitations. Most importantly, viral vectors are not cell-type specific on their own, so they do not allow for experiments that are "beyond the bolus" (Fig. 2A). In addition, this approach generally has low spatial resolution due to the difficulty in controlling the spread $(\sim 5-15 \mathrm{~kb})$ or a "bacterial artificial chromosome" (BAC) $(\sim 200$ $\mathrm{kb})$, typically by direct injection into the pronuclei of mouse oocytes. Generating transgenic mice using random insertion of the transgene of interest is relatively fast and easy, and there is potential for high levels of expression by incorporating multiple copies of the transgene. However, transgene expression may not fully recapitulate endogenous gene expression. Expression levels depend on the "chromatin context" of the transgene, which may be influenced by "cis-regulatory elements" such as enhancers, repressors, and insulators that are capable of acting over long distances (Heintzman and Ren 2009; Bulger and Groudine 2011). Furthermore, transgenes are susceptible to unpredictable alterations caused by epigenetic effects such as DNA methylation.

\section{Targeted insertion}

Targeted insertion of a transgene relies on homologous recombination to insert a transgene at the endogenous gene locus. This allows the transgene to be positioned within its native chromatin context alongside endogenous cis-regulatory elements. Therefore, targeted insertion is more likely than random insertion to recapitulate native gene expression, although it can still be susceptible to epigenetic effects. However, as the full expression pattern of a gene may include several cell types or brain regions, native gene expression may not always be optimal. As targeted insertion is a two-step 
process involving the breakage of DNA at a precise location and the insertion of a DNA fragment with homologous arms at that location, this approach is considered to be much slower and more complex than the random insertion of a DNA fragment wherever a break occurs. Alternative methods such as CRISPR (clustered regularly interspaced short palindromic repeats)/Cas may accelerate this process by facilitating RNA-guided site-specific DNA cleavage using designer nucleases at several sites within the genome simultaneously (Cong et al. 2013). Recently, the CRISPR/Cas system was used to generate mice carrying mutations (Wang et al. 2013) or reporter constructs (Yang et al. 2013) in multiple genes simultaneously. Therefore, this method has the potential to reduce both the time and complexity of generating targeted genetic manipulations in mice, and indeed holds the same promise for other species.

\section{Binary systems for transgene expression}

Binary systems utilize transgenic "driver" lines (i.e., Cre, Flp, tTA) which drive cell-type-specific expression of a "payload" transgene, delivered via crossing with a sec transgenic line or viral injection, which provides increased anatomical specificity (Fig. 2C). The two main binary systems are based on site-specific DNA recombination or transactivation (for a complete review of binary expression systems, see Ryding et al. 2001; Gossen and Bujard 2002; Lewandowski 2002).

\section{Site-specific DNA recombination}

The site-specific recombinases, Cre (Sauer 1998) and Flp (Dymecki 1996), are most frequently used for modulating gene expression through recombination. Cre recombinase, derived from the P1 bacteriophage, mediates recombination between loxP sites. Flp recombinase is derived from Sacchromyces cerevisiae and directs recombination between FRT sites. As the Cre/lox and Flp/FRT systems are conceptually identical, we will limit our discussion to the more commonly used Cre/lox system, which can be used to induce expression of a transgene using one of two methods. In the "floxed STOP" method, loxP sites surround a "STOP" DNA fragment upstream of the transgene, which prevents transcription and translation (Fig. 3A). Cre excises the "STOP" fragment, resulting in the activation of the transgene only in cells that express Cre. In contrast, in the doublefloxed inverted open reading frame (DIO or "FLEX") method, the transgene is situated in the reverse orientation and is flanked by two loxP sites (Fig. 3B). In the presence of Cre, the reading frame is inverted and one of the loxP sites is excised. This locks the reading frame in the correct orientation and enables strong expression of the transgene. Inducible forms of Cre can be used to precisely control both the timing and site of recombination. For example, the fusion protein CreER was generated by fusing Cre with the ligand-binding domain of human estrogen receptor (ER) (Metzger et al. 1995). Administration of tamoxifen induces Cre recombinase activity, which is not detectable in the absence of tamoxifen.

\section{Transactivation}

The most commonly used transactivation system in the mouse is the tTA-tetO system (Gossen and Bujard 1992), which uses a hybrid bacterial-viral transactivator (tTA) binding to a hybrid promoter containing tetracycline responsive elements (TREs) controlling the expression of the payload transgene. In the original "tet-off" system, tTA cannot bind TRE when the inducer doxycycline (Dox) is present, inhibiting expression of the transgene (Fig. 3C). Expression of the transgene occurs when tTA binds TRE following the removal of Dox from the animal's diet. In the modified "tet-on" system, "reverse tTA" (rtTA) binds TRE only
A

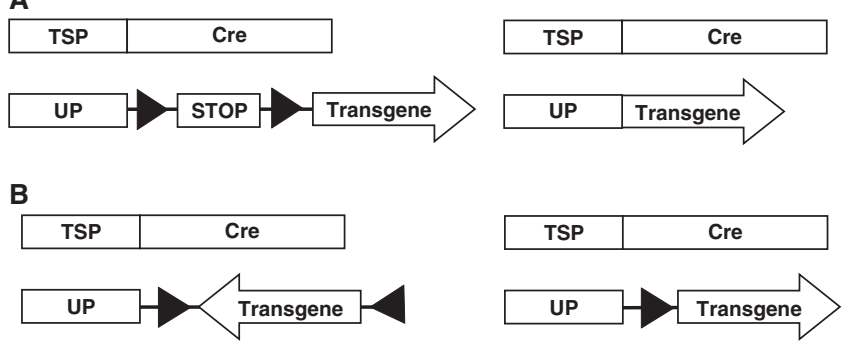

C

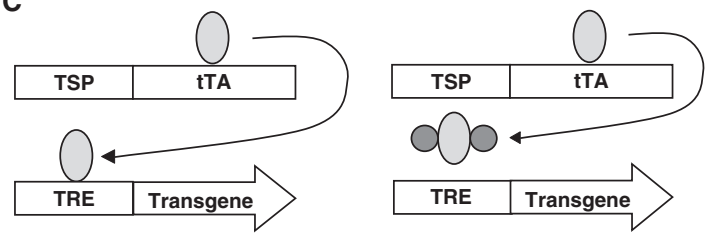

D

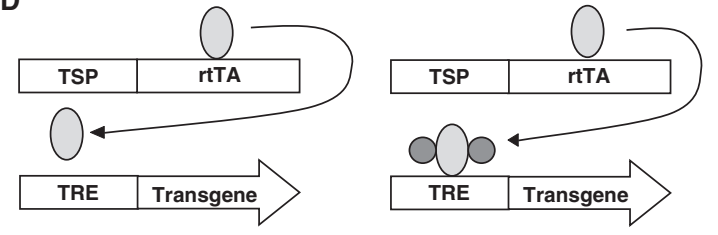

Figure 3. Binary systems for transgene expression. $(A, B)$ Cre/loxP system for site-specific DNA recombination. ( $A$ ) Floxed STOP method. Cre binds DNA at loxP sites and excises the STOP fragment, permitting transgene expression in a cell-specific manner. (B) Doublefloxed inverted open reading frame (DIO/FLEX) method. Cre binds DNA at loxP sites and inverts transgene DNA fragment, facilitating transgene expression in a cell-specific manner. (TSP) tissue-specific promoter, (UP) ubiquitous promoter, (STOP) transcription STOP site. (Black arrows) loxP sites. $(C, D)$ tTA/tetO transactivation system. (C) "Tet-off" system. (Left) Dox absent: tTA protein binds to TRE to activate cell-type-specific expression of transgene. (Right) Dox present: tTA cannot bind TRE; no expression of transgene occurs. (D) "Tet-on" system. (Left) Dox absent: rtTA protein cannot bind TRE; no expression of transgene occurs. (Right) Dox present: rtTA-Dox complex binds TRE, facilitating cell-type-specific expression of transgene. (TSP) tissue-specific promoter, (tTA, rtTA [light gray]) tetracycline transactivator protein, (TRE) tet-response element, (Dox [dark gray]) doxycycline.

when Dox is present, which rapidly induces transgene expression (Fig. 3D; Berens and Hillen 2004). The tetracycline transactivation system can be used for activity-dependent targeting, which utilizes promoters of immediate early genes (IEGs) such as c-fos and Arc to drive expression in neurons sufficiently active to induce IEG activity. Several activity-dependent lines have been generated, including c-fos-tTA (Reijmers et al. 2007), c-fos-GFP (Barth et al. 2004) transgenic lines and an Arc-GFP knock-in line (Wang et al. 2006).

\section{Transgenic manipulation of neural activity}

\section{Receptor-ligand systems}

Early approaches

One of the first approaches to precisely manipulate neural activity in anatomically defined neurons was the overexpression of the temperature-sensitive Drosophila melanogaster mutant gene shibire $^{t s 1}$ (Kitamoto 2001). Shibire interferes with endosomal trafficking, blocking neurotransmission, resulting in temperaturedependent changes in fly behavior. Following this development, several groups used targeted expression of native ion channels to directly silence neural activity in both flies and mice (Nitabach 
et al. 2002; Yu et al. 2004; Wulff et al. 2007). Unfortunately, these approaches suffer from slow temporal induction and are complicated by unwanted side effects due the constitutive expression of ion channels or blockade of neurotransmission (Table 3 ).

Therefore, several attempts were made to manipulate neural activity using targeted expression of ligand-gated ion channels (LGICs). The first of these attempts was the photochemical gating of the TRPV1 vanilloid receptor, which normally causes membrane depolarization in the presence of its ligand capsaicin (Zemelman et al. 2003). In this study, light was used to uncage a caged capsaicin derivative, which generated reliable and temporally precise action potentials in cultured hippocampal neurons. In a recent study, artificial activation of an ensemble of neurons in the lateral amygdala that coexpressed the TRPV1 receptor with a CREB-GFP fusion protein was sufficient to recall established fear memory (Kim et al. 2014). Activation of TRPV1 in genetically defined neural populations leads to robust, reversible, and rapid onset and offset of neurons (Guler et al. 2012). However, use of the TRPV1 system is complicated by baseline effects of the TRPV1 receptor in the absence of capsaicin, excitotoxicity resulting from high concentrations of capsaicin, and peripheral effects of capsaicin.

Selective expression of the allatostatin G-protein-coupled receptor (AlstR) from D. melanogaster was one of the first approaches used to inhibit neural activity in mammals by indirectly altering membrane excitability. In 2002, Lechner et al. expressed AlstR, which couples to the $G_{\mathrm{i} / \mathrm{o}}$ pathway to modulate GIRK channel activity, in cultured mammalian cortical neurons. Administration of the AlstR ligand allatostatin (AL) resulted in rapid and reversible inactivation. Neuronal inactivation via selective expression of AlstR has been demonstrated in vivo in mice, rats, ferrets, and monkeys using viral infection and transgenic approaches (Gosgnach et al. 2006; Tan et al. 2006, 2008; Wehr et al. 2009). In fact, inactivation of excitatory pyramidal neurons or inhibitory interneurons in CA1 using selective expression of AlstR disrupted the formation of long-term object location memory in mice (Haettig et al. 2013). The AlstR-AL system is selective, reversible, and potent. However, AL must be applied via invasive techniques due to the restricted diffusion of the peptide $(\sim 1 \mathrm{~mm})$ and its inability to cross the blood-brain barrier.

In contrast to the indirect modulation produced by the AlstRAL system, expression of a modified glutamate- and ivermectingated channel $(\mathrm{GluCl} \alpha \beta)$ from Caenorhabditis elegans directly prevents action potentials by hyperpolarizing the membrane upon systemic administration of ivermectin (Slimko et al. 2002). Striatal expression of GluCl $\alpha \beta$ resulted in rapidly suppressed spiking as well as amphetamine-induced rotational behavior in mice without causing neural or organismal toxicity (Lerchner et al. 2007). However, the utility of this approach is limited by the slow onset $(\sim 1 \mathrm{~d})$ and prolonged recovery $(\sim 4$ d) observed with systemic administration, variability in receptor expression, and the necessity of both $\alpha$ and $\beta$ subunits (Lerchner et al. 2007). In addition, ivermectin is known to cause toxicity at high concentrations (Dadarkar et al. 2007).

In order to generate silencing of mammalian neurons by inhibiting neurotransmitter release in vitro and in vivo, Karpova et al. (2005) developed molecules of inactivation of synaptic transmission (MISTs). These modified presynaptic proteins interfere with synaptic transmission by inducing dimerization in the presence of "dimerizers." The investigators generated MISTs by fusing synaptic vesicle proteins such as VAMP2/Synaptobrevin or Synaptophysin to the FK506 binding protein (FKBP). In the presence of an FKBP ligand, the fusion protein dimerizes and sequesters the presynaptic proteins, inhibiting normal transmitter release and the subsequent spread of action potentials. Application of dimerizers in vitro results in a rapid decrease in excitatory postsynaptic potentials (EPSPs) selectively in neurons expressing MISTs. Furthermore, dimerizer administration in transgenic mice expressing MISTs in cerebellar Purkinje neurons reduced both learning and performance on the rotarod task (Karpova et al. 2005). MISTs produce specific, inducible, and reversible silencing of neurons; however, the temporal control is insufficient for many applications. In addition, dimerizers must be administered intraventricularly as the permeability of the blood-brain barrier to dimerizers is low.

\section{RASSLs: receptors activated solely by synthetic ligands}

The first attempt to use G-protein-coupled receptors (GPCRs) to manipulate neural activity involved the mutation of the $\beta 2$ adrenergic receptor at asparagine residue 113 in order to disrupt native ligand binding (Strader et al. 1991). Although endogenous agonists still weakly activated the mutagenized receptor, normally inactive ligands acted as potent agonists. This development led to several attempts to mutate GPCRs in order to create selectively activated designer receptors. In 1998, Coward et al. created the Ro1 RASSL based on the $\mathrm{G}_{\mathrm{i}}$-coupled human $\kappa$ opioid receptor. This manipulation preserved the ability of synthetic small molecules to act as agonists at the receptor, while eliminating the response to more than 20 endogenous peptide ligands. By mutating Ro1, the investigators also created the Ro2 RASSL, which further decreased the affinity of endogenous opioids. Following this development, a variety of RASSLs were engineered to target each of the G protein signaling pathways (Kristiansen et al. 2000; Srinivasan et al. 2003; Bruysters et al. 2005). Unfortunately, the majority of RASSLs are applicable only in vitro due to insufficient in vivo selectivity. The utility of this approach is limited further by baseline receptor activity, off-target effects of synthetic ligands, and the lack of temporal control over RASSL signaling.

\section{DREADDs: designer receptors exclusively activated by designer drugs}

In an attempt to overcome the shortcomings of the first-generation RASSLs, Armbruster et al. (2007) generated a family of DREADDs. Introducing just two mutations into the $G_{\mathrm{q}}$-coupled human M3 muscarinic acetylcholine (ACh) receptor rendered it insensitive to its endogenous ligand clozapine and highly sensitive to the exogenous ligand clozapine- $\mathrm{N}$-oxide (CNO). CNO easily crosses the blood-brain barrier and does not have any off-target effects. This $G_{\mathrm{q}}$-coupled $\mathrm{hM} 3$ DREADD $\left(\mathrm{hM}_{3} \mathrm{D}_{\mathrm{q}}\right)$ stimulates phospholipase $\mathrm{C}$, resulting in depolarization due to increased membrane excitability. In addition, a $G_{\mathrm{i}}$-coupled DREADD was derived from the human M4 muscarinic receptor $\left(\mathrm{hM}_{4} \mathrm{D}_{\mathrm{i}}\right)$. In cultured neurons, $\mathrm{hM}_{4} \mathrm{D}_{\mathrm{i}}$ stimulates calcium release and activates GIRK, leading to hyperpolarization and inhibition of action potentials (Armbruster et al. 2007). The DREADD system offers many advantages, including bidirectional, long-lasting neuronal modulation, which is ideal for studying steady-state network responses in vivo. Effects develop after $\sim 15 \mathrm{~min}$, peak $1 \mathrm{~h}$ postinjection, and last for $>10 \mathrm{~h}$. Furthermore, DREADDs demonstrate no apparent baseline activity and cannot be activated by other ligands (including endogenous acetylcholine). Finally, CNO is easy to administer via noninvasive oral delivery or systemic injection and does not induce pathological effects.

The effectiveness of the DREADD system has been demonstrated repeatedly in awake, behaving animals. Alexander et al. (2009) created a line of double-transgenic mice expressing $\mathrm{hM}_{3} \mathrm{D}_{\mathrm{q}}$ in the forebrain using the tTA-tetO transactivation system with the CaMKII $\alpha$ promoter (Mayford et al. 1996). Administration of CNO resulted in the depolarization of hippocampal neurons in vitro as well as in $\mathrm{hM}_{3} \mathrm{D}_{\mathrm{q}}$-expressing transgenic mice. By expressing the $\mathrm{hM}_{3} \mathrm{D}_{\mathrm{q}}$ receptor in an activity-dependent manner using 
Table 3. Receptor-ligand systems

\begin{tabular}{|c|c|c|c|c|c|c|}
\hline Receptor & Ligand & Receptor type & Effect & Expression onset & Expression reversal & $\begin{array}{l}\text { Cross } \\
\text { BBB? }\end{array}$ \\
\hline Kir 2.1 & $\mathrm{~N} / \mathrm{A}$ & lonotropic & Inhibition & Constitutive & Constitutive & $\mathrm{N} / \mathrm{A}$ \\
\hline $\begin{array}{l}\text { Advantages } \\
\text { Limitations }\end{array}$ & \multicolumn{6}{|c|}{$\begin{array}{l}\text { Enables determination of role of spontaneous neural activity } \\
\text { Constitutive expression of channels causes unwanted side effects } \\
\text { Slow temporal induction }\end{array}$} \\
\hline $\mathrm{GABA}_{\mathrm{A}}$ & Zolpidem & Ionotropic & Inhibition & DA: seconds-minutes Sys: minutes & Sys: minutes & Yes \\
\hline Advantages & \multicolumn{6}{|c|}{$\begin{array}{l}\text { Systemic application } \\
\text { Bidirectional modulation in same animal with zolpidem or inverse agonist DMCM } \\
\text { Ligands antagonized with application of flumazenil } \\
\text { Genetically engineered zolpidem-insensitive background required limits application }\end{array}$} \\
\hline TRPV1 & Capsaicin & Ionotropic & Activation & DA: seconds & DA: seconds & Unknown \\
\hline Advantages & \multicolumn{6}{|c|}{$\begin{array}{l}\text { Temporally precise } \\
\text { High specificity } \\
\text { Depolarization does not attenuate with multiple light pulses } \\
\text { Baseline effects in the absence of ligand } \\
\text { Excitotoxicity in the presence of high agonist concentrations } \\
\text { Potential off-target peripheral effects of capsaicin }\end{array}$} \\
\hline AlstR & Allatostatin & lonotropic & Inhibition & DA: minutes & DA: minutes-hours & No \\
\hline Advantages & \multicolumn{6}{|c|}{$\begin{array}{l}\text { Highly potent, selective ligand } \\
\text { Cognate ligands inactive at AlstR } \\
\text { Silences without desensitization } \\
\text { Mammals do not endogenously express AlstR or AL } \\
\text { Invasive application of allatostatin } \\
\text { Activity limited by diffusion of allatostatin } \\
\text { Temporal control depends on ability to wash out ligand } \\
\text { May require cotransfection of GIRK channel subunits due to low endogenous GIRK expression }\end{array}$} \\
\hline GluCl $\alpha \beta$ & Ivermectin & lonotropic & Inhibition & DA: seconds-minutes Sys: hours & DA: hours Sys: hours & Yes \\
\hline $\begin{array}{l}\text { Advantages } \\
\text { Limitations }\end{array}$ & \multicolumn{6}{|c|}{$\begin{array}{l}\text { No neural or organismal toxicity at low concentrations } \\
\text { Slow onset and prolonged recovery with systemic administration } \\
\text { Variability in receptor expression } \\
\text { Both } \mathrm{GluCl} \alpha \text { and } \beta \text { subunits required } \\
\text { Ivermection causes toxicity at high concentrations }\end{array}$} \\
\hline VAMP2/Synaptobrevin & FKBP & Ionotropic & Inhibition & DA: minutes Sys: minutes & DA: hour Sys: days & Unknown \\
\hline $\begin{array}{l}\text { Advantages } \\
\text { Limitations }\end{array}$ & \multicolumn{6}{|c|}{$\begin{array}{l}\text { Inhibition highly selective for neurons expressing MISTs } \\
\text { Insufficient temporal control } \\
\text { Unknown permeability of BBB; intraventricular administration required } \\
\text { Potential off-target actions }\end{array}$} \\
\hline PSAM-GlyR & PSEMs & Ionotropic & Inhibition & DA: seconds-minutes Sys: minutes & DA: seconds-minutes & Yes \\
\hline $\begin{array}{l}\text { Advantages } \\
\text { Limitations }\end{array}$ & \multicolumn{6}{|c|}{$\begin{array}{l}\text { Potential manipulation of several ionic conductances simultaneously } \\
\text { Kinetics depend on combination of ligand-binding and ion pore domains } \\
\text { Kinetics depend on pharmacokinetic properties of ligand }\end{array}$} \\
\hline PSAM- $5 \mathrm{HT}_{3}$ & PSEMs & lonotropic & Inhibition & DA: sec & DA: sec & Yes \\
\hline $\begin{array}{l}\text { Advantages } \\
\text { Limitations }\end{array}$ & \multicolumn{6}{|c|}{$\begin{array}{l}\text { Potential manipulation of several ionic conductances simultaneously } \\
\text { Kinetics depend on combination of ligand-binding and ion pore domains } \\
\text { Kinetics depend on pharmacokinetic properties of ligand }\end{array}$} \\
\hline RASSLs Ro1, Ro2 & Spiradoline Gramine & Metabotropic & Activation & DA: seconds-minutes Sys: minutes & DA: hours & Yes \\
\hline Advantages & \multicolumn{6}{|c|}{$\begin{array}{l}\text { Broad spectrum of effects (G-protein coupled) } \\
\text { Insensitive to many endogenous agonists } \\
\text { Sensitivity to synthetic agonists } \\
\text { Synthetic ligands do not solely activate designer receptors } \\
\text { Pathologic conditions in multiple tissues } \\
\text { Constitutive activity of receptor } \\
\text { Low temporal resolution }\end{array}$} \\
\hline $\mathrm{hM}_{3} \mathrm{D}_{\mathrm{q}}$ & CNO & Metabotropic & Activation & DA: seconds-minutes Sys: minutes & Sys: hours & Yes \\
\hline Advantages & \multicolumn{6}{|c|}{$\begin{array}{l}\text { No baseline receptor activity } \\
\text { Cannot be activated by other ligands } \\
\text { Inert synthetic ligand } \\
\text { Noninvasive administration of CNO } \\
\text { Low temporal resolution }\end{array}$} \\
\hline $\mathrm{hM}_{4} \mathrm{D}_{\mathrm{i}}$ & $\mathrm{CNO}$ & Metabotropic & Inhibition & DA: seconds-minutes Sys: hours & Sys: hours & Yes \\
\hline Advantages & \multicolumn{6}{|c|}{$\begin{array}{l}\text { No baseline receptor activity } \\
\text { Cannot be activated by other ligands (including acetylcholine) } \\
\text { Inert synthetic ligand } \\
\text { Noninvasive administration of CNO } \\
\text { Low temporal resolution }\end{array}$} \\
\hline
\end{tabular}

For a complete review of receptor-ligand systems, see Rogan and Roth (2011); Nichols and Roth (2009); Wulff and Arenkiel (2012); and Tervo and Karpova (2007).

(DA) Direct application to tissue in vitro or in vivo, (Sys) systemic application in vivo.

Estimates for expression onset and reversal are approximations and may vary across applications. 
the c-fos-tTA transgenic line (Reijmers et al. 2007), Garner et al. (2012) investigated how internally generated activity influences the formation of a new memory representation. Neurons sufficiently active during an initial sensory experience in one context (CtxA) were reactivated following administration of CNO during subsequent fear conditioning in a distinct context (CtxB). This manipulation resulted in the formation of a hybrid memory representation: Mice showed significant freezing behavior only when $\mathrm{CNO}$ was administered in CtxB during a memory test $24 \mathrm{~h}$ later. In 2011, Ferguson et al. demonstrated that CNO-induced activation of $\mathrm{hM}_{4} \mathrm{D}_{\mathrm{i}}$ receptors hyperpolarized striatal neurons in vitro. In addition, administration of $\mathrm{CNO}$ to rats expressing $\mathrm{hM}_{4} \mathrm{D}_{\mathrm{i}}$ receptors in the ventral tegmental area blocked dopamine release and inhibited amphetamine-induced $c$-fos expression. Although the transient disruption of indirect striatopallidal pathway neurons facilitated behavioral sensitization, the disruption of neurons in the direct striatonigral pathway inhibited behavioral sensitization. Finally, Zhu et al. (2014) selectively inactivated glutamatergic CA1 neurons in the ventral hippocampus using $\mathrm{hM}_{4} \mathrm{D}_{\mathrm{i}} 6 \mathrm{~h}$ after fear conditioning. This manipulation impaired consolidation of contextual fear memory without affecting cued fear memory. Together, these results demonstrate that DREADDs are a useful tool for both activating and inhibiting neural activity.

\section{PSAMs: pharmacologically selective actuator modules}

By mutating the ligand-binding domain of the $\alpha 7$ nicotonic acetylcholine receptor (nAChR), Magnus et al. (2011) engineered a family of chimeric ligand-gated ion channels (LGICs). This manipulation reduced the sensitivity of the receptor to its endogenous ligand acetylcholine, while conferring increased sensitivity to a group of synthetic pharmacologically selective effector molecules (PSEMs). Fusion of the modified ligand-binding domains, referred to as PSAMs, with the ion pore domains of serotonin receptor $3 \mathrm{a}\left(\alpha_{7}-5 \mathrm{HT}_{3}\right)$ or the glycine receptor $\left(\alpha_{7}-\mathrm{GlyR}\right)$ resulted in LGICs capable of rapid activation and inhibition, respectively (Magnus et al. 2011). In 2013, Basu et al. injected a Cre-dependent viral vector to coexpress the glycine receptor-based PSAM (PSAMGlyR) and channelrhodopsin-2 (ChR2) in the CA1 subregion of the hippocampus of cholecystokinin-Cre (CCK-Cre) transgenic mice. Application of the PSEM ligand resulted in the rapid and selective silencing of CCK+ neurons. Their results demonstrated that CCK-expressing interneurons are responsible for the majority of feedforward input that controls synaptic responses of CA1 pyramidal neurons elicited by both Schaffer collateral and perforant path inputs. Advantageously, chimeric LGICs have orthogonal ion selectivities, potentially enabling the manipulation of separate ionic conductances of different neurons in the same animal. However, the exact on/off kinetics will depend on the combination of ligand-binding and ion pore domains, as well as the pharmacokinetic properties of the native ligand.

\section{Microbial opsins}

\section{Activation}

Over the last decade, a large assortment of microbial opsins have been developed, enabling millisecond timescale control of neural activity in response to light in a cell-type-specific manner (Table 4; for a complete review of optogenetic tools, see Fenno et al. 2011; Yizhar et al. 2011a; Zhang et al. 2011). In 2005, Boyden et al. reported their discovery that illumination of the light-gated cationselective channel channelrhodopsin-2 with $470 \mathrm{~nm}$ blue light rapidly causes large, depolarizing currents in hippocampal neurons. In order to resolve the inherent limitations of ChR2, several groups subsequently engineered ChR2 variants. By mutating the ChR2 histidine residue at position 134 to arginine, Gradinaru et al. (2007) created the ChR2(H134) opsin, which increased peak photocurrents by approximately twofold. However, this manipulation also delayed channel closure, impairing temporal precision. In 2009, Lin et al. developed ChEF, a chimera of the transmembrane domains of ChR1 and ChR2, which undergoes less inactivation during persistent light stimulation than wildtype ChR2. A single point mutation of ChEF yielded ChIEF, which exhibits reduced desensitization, improved kinetics, and stronger currents than wild-type ChR2 in cultured hippocampal neurons (Lin et al. 2009). Finally, Gunaydin et al. (2010) mutated residue E123 of ChR2 to threonine or alanine (ChETA), which resulted in reduced desensitization and accelerated channel closure. Because of the decrease in channel open time, the peak photocurrent of ChETA is slightly smaller than wild-type ChR2; however, longer or more intense light pulses compensate for this limitation. Notably, both ChIEF and ChETA can be used to evoke ultrafast firing frequencies (up to $200 \mathrm{~Hz}$ ) with high signal fidelity (Yizhar et al. 2011a).

By mutating the cysteine residue at position 128 in ChR2 to serine, alanine, or threonine, Berndt et al. (2009) developed the step-function opsins (C128 SFOs), which produce sustained, bistable step depolarization of membrane potential. The SFOs are activated in response to a single pulse of blue light with dramatically increased light sensitivity relative to ChR2. Single pulses of green light result in rapid and complete inactivation. In response to persistent light stimulation, the SFOs display prolonged activity with inactivation time constants of minutes rather than milliseconds. In fact, the D156A SFO developed by Bamann et al. (2010) exhibits an inactivation constant of nearly $8 \mathrm{~min}$. However, the membrane depolarizations induced by SFOs are not sufficiently stable following a single light pulse. Therefore, Yizhar et al. (2011b) combined the C128S and D156A mutations in order to generate a stabilized SFO (SSFO). SSFOs exhibit drastically increased sensitivity to light and an inactivation time constant of $\sim 30 \mathrm{~min}$, which enables noninvasive light-induced activation of neurons during behavioral protocols.

In order to selectively control two separate populations of neurons simultaneously, several groups have engineered opsins activated by red-shifted wavelengths. VChR1, a red-shifted version of ChR2 that responds to $545 \mathrm{~nm}$ light was developed using a cation-conducting channelrhodopsin from $V$. carteri (Zhang et al. 2008). Unfortunately, VChR1 generates relatively small photocurrents due to low expression in mammalian neurons. Therefore, Yizhar et al. (2011b) engineered C1V1, a chimeric opsin composed of ChR1 and VChR1 helices, which has a peak activation wavelength of $\sim 560 \mathrm{~nm}$. C1V1 exhibits reduced inactivation and improved expression in mammalian cells. The investigators achieved combinatorial excitation in vitro and in vivo by delivering different wavelengths of light to pyramidal neurons expressing C1V1 and parvalbumin neurons expressing ChR2(H134) in the medial prefrontal cortex. ReaChR, a recently developed red-activatable channelrhodopsin, offers improved membrane trafficking, higher photocurrents, and faster kinetics than previous redshifted variants (Lin et al. 2013). ReaChR is optimally excited by orange to red light of $\sim 590-630 \mathrm{~nm}$, resulting in less light scattering and less absorption by the blood than with wavelengths used by other channelrhodopsin variants. Finally, Chuong et al. (2014) recently developed the red-shifted cruxhalorhodopsin Jaws, derived from Haloarcula salinarum, which results in noninvasive optical inhibition of subcortical neurons.

\section{Inhibition}

Microbial opsins can also generate hyperpolarizing currents in response to sustained light stimulation. In 2007, Zhang et al. used constant yellow light to activate a halorhodopsin chloride 
Table 4. Opsins

\begin{tabular}{|c|c|c|c|c|}
\hline Opsin & Host organism & Effect & $\lambda$ & $T_{\text {off }}$ \\
\hline ChR2 & Chlamydomonas reinhardtii & Activation & $470 \mathrm{~nm}$ & $\sim 10 \mathrm{msec}$ \\
\hline Advantages/limitations & \multicolumn{4}{|c|}{$\begin{array}{l}\text { Greater expression level than ChR1 } \\
\text { Deactivation time constant imposes a limit on temporal precision } \\
\text { Desensitization in the presence of light } \\
\text { Limited expression in mammalian systems }\end{array}$} \\
\hline ChR2(H134) & C. reinhardtii & Activation & $470 \mathrm{~nm}$ & $18 \mathrm{msec}$ \\
\hline Advantages/limitations & \multicolumn{4}{|c|}{$\begin{array}{l}\text { Increased peak photocurrents approximately twofold } \\
\text { Delayed channel closure } \\
\text { Impaired temporal precision and high speed spiking }\end{array}$} \\
\hline ChEF, ChIEF & C. reinhardtii & Activation & $450 \mathrm{~nm}$ & $\sim 10 \mathrm{msec}$ \\
\hline Advantages/limitations & \multicolumn{4}{|c|}{$\begin{array}{l}\text { Reduced desensitization } \\
\text { Improved kinetics } \\
\text { Stronger currents } \\
\text { Evokes ultrafast firing frequencies }\end{array}$} \\
\hline ChETA E123A, E123T & C. reinhardtii & Activation & $470 \mathrm{~nm}, 500 \mathrm{~nm}$ & $4 \mathrm{msec}, 4.4 \mathrm{msec}$ \\
\hline Advantages/limitations & \multicolumn{4}{|c|}{$\begin{array}{l}\text { Reduced desensitization } \\
\text { Faster channel closure } \\
\text { More robust spiking, reduced extra spikes, reduced plateau potentials } \\
\text { Evokes ultrafast firing frequencies } \\
\text { Slightly lower sensitivity due to shorter open time }\end{array}$} \\
\hline $\begin{array}{l}\text { SFOs ChR2(C128S), } \\
\text { ChR2(D156A) }\end{array}$ & C. reinhardtii & Activation & $\begin{array}{l}470 / 560 \mathrm{~nm} \\
470 / 590 \mathrm{~nm}\end{array}$ & $\begin{array}{l}1.7 \mathrm{~min} \\
6.9 \mathrm{~min}\end{array}$ \\
\hline Advantages/limitations & \multicolumn{4}{|c|}{$\begin{array}{l}\text { Bistable membrane depolarization } \\
\text { Increased inactivation time constants } \\
\text { Activation/inactivation with a single light pulse } \\
\text { Greater light sensitivity of transduced cells } \\
\text { Membrane depolarization not sufficiently stable following single light pulse }\end{array}$} \\
\hline SSFOs ChR2(C128S/D156A) & C. reinhardtii & Activation & $445 / 590 \mathrm{~nm}$ & $29 \min$ \\
\hline Advantages/limitations & \multicolumn{4}{|c|}{$\begin{array}{l}\text { Bistable membrane depolarization } \\
\text { Increased long inactivation time constant } \\
\text { Activation/inactivation with a single light pulse } \\
\text { Greater light sensitivity of transduced cells } \\
\text { Ability to conduct experiments in the absence of tethered light delivery }\end{array}$} \\
\hline VChR1 & Volvox carteri & Activation & $545 \mathrm{~nm}$ & $133 \mathrm{msec}$ \\
\hline Advantages/limitations & \multicolumn{4}{|c|}{$\begin{array}{l}\text { Responds to red-shifted } \lambda \\
\text { Enables simultaneous control of two separate neural populations } \\
\text { Low expression in mammalian neurons due to small currents }\end{array}$} \\
\hline $\begin{array}{l}\text { C1V1 (E162T), (E162T/ } \\
\text { E122T) }\end{array}$ & C. reinhardtii & Activation & $535 \mathrm{~nm}, 545 \mathrm{~nm}$ & $50 \mathrm{msec}, 38 \mathrm{msec}$ \\
\hline Advantages/limitations & \multicolumn{4}{|c|}{$\begin{array}{l}\text { Improved membrane trafficking in mammalian cells } \\
\text { Reduced inactivation } \\
\text { Less light scattering due to short illumination times and low laser power }\end{array}$} \\
\hline ReaChR & C. reinhardtii & Activation & $590 \mathrm{~nm}$ & $21 \mathrm{msec}$ \\
\hline Advantages/limitations & \multicolumn{4}{|c|}{$\begin{array}{l}\text { Responds to red-shifted } \lambda \\
\text { Less light scattering; less light absorption by blood } \\
\text { Slower channel closure rate after termination of light vs. C1V1 }\end{array}$} \\
\hline eNpHR(3.0) & Natronomonas pharaonis & Inhibition & $590 \mathrm{~nm}$ & $4.2 \mathrm{msec}$ \\
\hline Advantages/limitations & \multicolumn{4}{|c|}{$\begin{array}{l}\text { Improved membrane trafficking vs. NpHR } \\
\text { Increased peak photocurrents } \\
\text { Increased sensitivity } \\
\text { Temporal precision limit }\end{array}$} \\
\hline ArchT & Halorubrum sodomense & Inhibition & $566 \mathrm{~nm}$ & $9 \mathrm{msec}$ \\
\hline Advantages/limitations & \multicolumn{4}{|c|}{$\begin{array}{l}\text { Capable of complete neuronal silencing } \\
\text { Higher resistance to inactivation vs. NpHR } \\
\text { Stronger inhibition vs. NpHR } \\
\text { Increased light sensitivity vs. Arch } \\
\text { Possible negative consequences due to addition of protons to extracellular space }\end{array}$} \\
\hline $\begin{array}{l}\mathrm{iClC2} \\
\text { SwiChR }_{\mathrm{CA}} \\
\quad \text { Advantages/limitations }\end{array}$ & \multicolumn{4}{|c|}{$\begin{array}{l}\text { Fast optical inhibition } \\
\text { Step-function kinetics for stable inhibition, outlasting light pulses } \\
\text { Dramatically increased light sensitivity }\end{array}$} \\
\hline
\end{tabular}

For a complete review of opsins/optogenetics, see Fenno et al. (2011); Yizhar et al. (2011a); Zhang et al. (2011).

( $\lambda$ ) Peak activation wavelength, $\left(\tau_{\text {off }}\right)$ off kinetics. 
pump (NpHR) derived from N. pharaonis, resulting in the hyperpolarization of target neurons (Zhang et al. 2007). Due to poor membrane trafficking, several modifications were made to $\mathrm{NpHR}$, which resulted in improved surface membrane expression, increased peak photocurrents, and increased light sensitivity [eNpHR(2.0), eNpHR(3.0)] (Gradinaru et al. 2008, 2010). Recently, Wietek et al. (2014) and Berndt et al. (2014) used structure-based molecular engineering to convert channelrhodopsin into a lightgated chloride channel, resulting in improved neuronal silencing. In addition, light-activated proton pumps, including MAC, eBR, Arch, and ArchT have also been used to generate sustained hyperpolarization (Chow et al. 2010; Han et al. 2011). In fact, Arch facilitates complete neural silencing of cortical neurons in awake, behaving mice (Chow et al. 2010). ArchT, an archaerhodopsin from a related $H$. sodomense strain, is $3.5 \times$ more light sensitive than Arch with strong expression on neural membranes and axons (Han et al. 2011). However, proton pumps are not as kinetically stable or as potent as eNpHR. In addition, a major concern with proton pumps is potential deleterious or noncell-type-specific effects due to the increased concentration of protons in the extracellular space.

\section{Entorhinal-hippocampal anatomy}

The optogenetic approach has been used in a variety of studies to investigate the anatomy of the entorhinal-hippocampal circuit. In particular, Kitamura et al. (2014) identified clusters of excitatory neurons called "island cells" in MEC LII. To investigate the functional role of island cells, the investigators injected MEC LII of island cell-specific transgenic mice with Cre-dependent ChR2. Optogenetic stimulation of ChR2-expressing island cell axons confirmed that island cells project directly to CA1 to activate interneurons that target the distal dendrites of CA1 pyramidal neurons. Furthermore, optogenetic modulation of island cells during trace fear conditioning demonstrated that island cells are capable of suppressing MEC LIII input through feedforward inhibition, thereby controlling the strength and duration of temporal association memory. By combining optogenetics and patchclamp recordings in highly cell-type-specific transgenic mouse lines, Kohara et al. (2014) reported the existence of an alternate trisynaptic circuit in the hippocampus. Optogenetic stimulation of ChR2-expressing granule cells in a dentate gyrus granule cell (DGGC)-specific transgenic mouse line demonstrated that DGGCs project to CA2 pyramidal cells through a functional, monosynaptic excitatory pathway. In addition, optogenetic stimulation of ChR2-expressing CA2 fibers in a CA2-specific knock-in mouse line suggested that CA2 innervates the deep sublayers of CA1 to complete a previously unknown trisynaptic circuit. Finally, Zhang et al. (2013) combined optogenetics and electrophysiology to determine the functional identity of cells in the entorhinal cortex that project to place cells in the hippocampus. Injection of a recombinant AAV-ChR2 virus into the dorsal hippocampus restricted expression of ChR2 to hippocampus-targeting entorhinal projection neurons. As expected, the investigators demonstrated that a large number of spatially modulated entorhinal projection cells were grid cells. However, entorhinal projections also contained border cells, head direction cells, and nonspatial cells. These findings suggest that a variety of functional entorhinal cell types integrate information to generate place cells in the hippocampus.

\section{Entorhinal-hippocampal function}

Cell-type-specific expression of microbial opsins has also been used to investigate the role of the dentate gyrus in the formation of contextual fear memories. In 2012, Liu et al. injected ChR2 into the DG of $c$-fos-tTA transgenic mice. Mice were habituated to Context A while on doxycycline, inhibiting expression of the ChR2 transgene. Then, the mice underwent fear conditioning in Context B in the absence of doxycycline, restricting ChR2 expression to neurons sufficiently active during contextual fear conditioning. Interestingly, the mice exhibited significantly increased freezing behavior upon subsequent optical reactivation of labeled cells in Context A. However, the mice did not show a fear response in Context $\mathrm{B}$ or in a novel Context $\mathrm{C}$, suggesting that the reactivation of a sparse ensemble of DG neurons was sufficient to induce recall of a fear memory. Subsequently, Ramirez et al. (2013) induced the generation of a false memory in the hippocampus using the same combination of transgenic and optogenetic techniques. In this study, mice were habituated to Context A in the absence of doxycycline in order to label sufficiently active DG neurons. Then, in the presence of doxycycline, the mice were fear conditioned in Context B, whereas cells labeled in Context A were optically reactivated. Subsequent reexposure to Context A produced a fear response; however, the mice did not exhibit a freezing response in a novel Context C. Another group used cell-type-specific expression of microbial opsins to assess the role of granule cells in the dorsal versus ventral DG in contextual learning and anxiety (Kheirbek et al. 2013). The investigators activated or inhibited activity by injecting ChR2(H134R) or eNpHR(3.0), respectively, into the DG of transgenic mice. The dorsal DG was shown to be involved in the encoding, but not the retrieval, of contextual fear memories. In contrast, the ventral DG was not involved in contextual learning, but suppressed innate anxiety. Together, these results demonstrate that optogenetics is an innovative and powerful method for understanding both the anatomy and function of the entorhinal-hippocampal circuit.

\section{Conclusion}

The combination of viral tracing methods and in vivo electrophysiological recordings provides an unprecedented opportunity for researchers to investigate the anatomical connections between different cell types in the entorhinal-hippocampal circuit, as well as the rest of the brain. In addition, pharmaco- and optogenetic tools permit researchers to manipulate the activity of these neurons in a cell-type-specific manner with the goal of determining their role in spatial memory. Cell-specific modulation of neural activity may enable researchers to empirically test theoretical models of grid and place cell formation in the entorhinal-hippocampal circuit, determining the interrelationships between the different spatial RFs found in these regions and their relative contributions to navigation and spatial memory. Thus, more than 50 years after Hubel and Wiesel articulated the goal of determining how the RFs of upstream neurons could combine to generate the RFs of downstream neurons, the application of cell-specific molecular techniques may finally allow systems neuroscientists to make theoretical models empirically testable.

\section{Acknowledgments}

This research was supported by a National Institute of Mental Health grant (R01 MH097130).

\section{References}

Alexander GM, Rogan SC, Abbas AI, Armbruster BN, Pei Y, Allen JA, Nonneman RJ, Hartmann J, Moy SS, Nicolelis MA, et al. 2009. Remote control of neuronal activity in transgenic mice expressing evolved $\mathrm{G}$ protein-coupled receptors. Neuron 63: 27-39.

Armbruster BN, Li X, Pausch MH, Herlitze S, Roth BL. 2007. Evolving the lock to fit the key to create a family of $G$ protein-coupled receptors 
potently activated by an inert ligand. Proc Natl Acad Sci 104: 5163-5168.

Bamann C, Gueta R, Kleinlogel S, Nagel G, Bamberg E. 2010. Structural guidance of the photocycle of channelrhodopsin- 2 by an interhelical hydrogen bond. Biochemistry 49: 267-278.

Barry C, Lever C, Hayman R, Hartley T, Burton S, O'Keefe J, Jeffrey K, Burgess N. 2006. The boundary vector cell model of place cell firing and spatial memory. Rev Neurosci 17: 71-97.

Barry C, Ginzberg LL, O'Keefe J, Burgess N. 2012. Grid cell firing patterns signal environmental novelty by expansion. Proc Natl Acad Sci 109: 17687-17692.

Barth AL, Gerkin RC, Dean KL. 2004. Alteration of neuronal firing properties after in vivo experience in a FosGFP transgenic mouse. J Neurosci 24: 6466-6475.

Basu J, Srinivas KV, Cheung SK, Taniguchi H, Huang ZJ, Siegelbaum SA. 2013. A cortico-hippocampal learning rule shapes inhibitory microcircuit activity to enhance hippocampal information flow. Neuron 79: $1208-1221$.

Berens C, Hillen W. 2004. Gene regulation by tetracyclines. Genet Eng 26: $255-277$.

Berndt A, Yizhar O, Gunaydin LA, Hegemann P, Deisseroth K. 2009. Bi-stable neural state switches. Nat Neurosci 12: 229-234.

Berndt A, Lee SY, Ramakrishnan C, Deisseroth K. 2014. Structure-guided transformation of channelrhodopsin into a light-activated chloride channel. Science 344: 420-425.

Boyden ES, Zhang F, Bamberg E, Nagel G, Deisseroth K. 2005. Millisecond-timescale, genetically targeted optical control of neural activity. Nat Neurosci 8: 1263-1268.

Brandon MP, Bogaard AR, Libby CP, Connerney MA, Gupta K, Hasselmo ME. 2011. Reduction of $\theta$ rhythm dissociates grid cell spatial periodicity from directional tuning. Science 332: 595-599.

Brandon MP, Koenig J, Leutgeb JK, Leutgeb S. 2014. New and distinct hippocampal place codes are generated in a new environment during septal inactivation. Neuron 82: 789-796.

Brun VH, Otnass MK, Molden S, Steffenach HA, Witter MP, Moser MB, Moser EI. 2002. Place cells and place recognition maintained by direct entorhinal-hippocampal circuitry. Science 296: 2243-2246.

Bruysters M, Jongejan A, Akdemir A, Bakker RA, Leurs R. 2005. A G(q/11)-coupled mutant histamine (H1) receptor F435A activated solely by synthetic ligands (RASSL). J Biol Chem 280: 34741-34746.

Bulger M, Groudine M. 2011. Functional and mechanistic delivery of distal transcription enhancers. Cell 144: 327-339.

Burgess N, Barry C, O’Keefe J. 2007. An oscillatory interference model of grid cell firing. Hippocampus 17: 801-812.

Bush D, Barry C, Burgess N. 2014. What do grid cells contribute to place cell firing? Trends Neurosci 37: 136-145.

Chamberlin NL, Du B, de Lacalle S, Saper CB. 1998. Recombinant adeno-associated virus vector: use for transgene expression and anterograde tract tracing in the CNS. Brain Res 793: 169-175.

Chapman B, Zahs KR, Stryker MP. 1991. Relation of cortical cell orientation selectivity to alignment of receptive fields of the geniculocortical afferents that arborize within a single orientation column in ferret visual cortex. J Neurosci 11: 1347-1358.

Chow BY, Han X, Dobry AS, Qian X, Chuong AS, Li M, Henninger MA, Belfort GM, Lin Y Monahan PE, et al. 2010. High-performance genetically targetable optical neural silencing by light-driven proton pumps. Nature 463: 98-102.

Chuong AS, Miri ML, Busskamp V, Matthews GA, Acker LC, Sørensen AT, Young A, Klapoetke NC, Henninger MA, Kodandaramaiah SB, et al. 2014. Noninvasive optical inhibition with a red-shifted microbial rhodopsin. Nat Neurosci 17: 1123-1129.

Cong L, Ran FA, Cox D, Lin S, Barretto R, Habib N, Hsu PD, Xu W, Jiang W, Marraffini LA, et al. 2013. Multiplex genome engineering using CRISPR/Cas systems. Science 339: 819-823.

Coward P, Wada HG, Falk MS, Chan SDH, Meng F, Akil H, Conklin BR. 1998. Controlling signaling with a specifically designed Gi-coupled receptor. Proc Natl Acad Sci 95: 352-357.

Dadarkar SS, Deore MD, Gatne MM. 2007. Comparative evaluation of acute toxicity of ivermectin by two methods after single subcutaneous administration in rats. Regul Toxicol Pharmacol 47: 257-260.

Davidson BL, Breakefield XO. 2003. Viral vectors for gene delivery to the nervous system. Nat Rev Neurosci 4: 353-364.

de Almeida L, Idiart M, Lisman JE. 2009. The input-output transformation of the hippocampal granule cells: from grid cells to place fields. J Neurosci 29: 7504-7512.

Dymecki SM. 1996. Cre recombinase promotes site-specific DNA recombination in embryonic stem cells and transgenic mice. Proc Nat Acad Sci 93: 6191-6196.

Fenno L, Yizhar O, Deisseroth K. 2011. The development and application of optogenetics. Annu Rev Neurosci 34: 389-412.
Ferguson SM, Eskenazi D, Ishikawa M, Wanat MJ, Phillips PE, Dong Y, Roth BL, Neumaier JF. 2011. Transient neuronal inhibition reveals opposing roles of indirect and direct pathways in sensitization. Nat Neurosci 14: 22-24.

Fuhs MC, Touretzky DS. 2006. A spin glass model of path integration in rat medial entorhinal cortex. J Neurosci 26: 4266-4276.

Garner AR, Rowland DC, Hwang SY, Baumgaertel K, Roth BL, Kentros C, Mayford M. 2012. Generation of a synthetic memory trace. Science 335: $1513-1516$.

Geisler C, Robbe D, Zugaro M, Sirota A, Buzsáki G. 2007. Hippocampal place cell assemblies are speed- controlled oscillators. Proc Natl Acad Sci 104: 8149-8154.

Gosgnach S, Lanuza GM, Butt SJ, Saueressig H, Zhang Y, Velasquez T, Reithmacher D, Callaway EM, Kiehn O, Goulding M. 2006. V1 spinal neurons regulate the speed of vertebrate locomotor outputs. Nature 440: $215-219$.

Gossen M, Bujard H. 1992. Tight control of gene expression in mammalian cells by tetracycline-responsive promoters. Proc Natl Acad Sci 89: $5547-5551$.

Gossen M, Bujard H. 2002. Studying gene function in eukaryotes by conditional gene inactivation. Annu Rev Genet 36: 153-173.

Gradinaru V, Thompson KR, Zhang F, Mogri M, Kay K, Schneider MB, Deisseroth K. 2007. Targeting and readout strategies for fast optical neural control in vitro and in vivo. J Neurosci 27: 14231-14238.

Gradinaru V, Thompson KR, Deisseroth K. 2008. eNpHR: a Natronomonas halorhodopsin enhanced for optogenetic applications. Brain Cell Biol 36: $129-139$.

Gradinaru V, Zhang F, Ramakrishnan C, Mattis J, Prakash R, Diester I, Goshen I, Thompson KR, Deisseroth K. 2010. Molecular and cellular approaches for diversifying and extending optogenetics. Cell 141: $154-165$.

Grinevich V, Brecht M, Osten P. 2005. Monosynaptic pathway from rat vibrissa motor cortex to facial motor neurons revealed by lentivirus-based axonal tracing. I Neurosci 25: 8250-8258.

Guler AD, Rainwater A, Parker JG, Jones GL, Argilli E, Arenkiel BR, Ehlers MD, Bonci A, Zweifel LS, Palmiter RD. 2012. Transient activation of specific neurons in mice by selective expression of the capsaicin receptor. Nat Commun 3: 746.

Gunaydin LA, Yizhar O, Berndt A, Sohal VS, Deisseroth K, Hegemann P. 2010. Ultrafast optogenetic control. Nat Neurosci 13: 387-392.

Haettig J, Sun Y, Wood MA, Xu X. 2013. Cell-type specific inactivation of hippocampal CA1 disrupts location-dependent object recognition in the mouse. Learn Mem 20: 139-146.

Hafting T, Fyhn M, Molden S, Moser MB, Moser EI. 2005. Microstructure of a spatial map in the entorhinal cortex. Nature 436: 801-806.

Han X, Chow BY, Zhou HH, Klapoetke NC, Chuong A, Rajimehr R, Yang A, Baratta MV, Winkle J, Desimone R, et al. 2011. A high-light sensitivity optical neural silencer: development and application to optogenetic control of non-human primate cortex. Front Syst Neurosci 5: 1.

Harris JA, Oh SW, Zeng H. 2012. Adeno-associated viral vectors for axonal tracing with fluorescent proteins in nontransgenic and Cre driver mice. Curr Protoc Neurosci 59: 1.20.1-1.20.18.

Hartley T, Burgess N, Lever C, Cacucci F, O'Keefe J. 2000. Modeling place fields in terms of the cortical inputs to the hippocampus. Hippocampus 10: $369-379$.

Heintzman ND, Ren B. 2009. Finding distal regulatory elements in the human genome. Curr Opin Genet Dev 19: 541-549.

Hubel DH, Wiesel TN. 1959. Receptive fields of single neurones in the cat's striate cortex. J Physiol 148: 574-591.

Hubel DH, Wiesel TN. 1962. Receptive fields, binocular interaction and functional architecture in the cat's visual cortex. J Physiol 160: $106-154$.

Jeewajee A, Barry C, O'Keefe J, Burgess N. 2008. Grid cells and $\theta$ as oscillatory interference: electrophysiological data from freely moving rats. Hippocampus 18: $1175-1185$.

Karpova AY, Tervo DG, Gray NW, Svoboda K. 2005. Rapid and reversible chemical inactivation of synaptic transmission in genetically targeted neurons. Neuron 48: 727-735.

Kheirbek MA, Drew LJ, Burghardt NS, Costantini DO, Tannenholz L, Ahmari SE, Zeng H, Fenton AA, Hen R. 2013. Differential control of learning and anxiety along the dorsoventral axis of the dentate gyrus. Neuron 77: 955-968.

Kim J, Kwon JT, Kim HS, Josselyn SA, Han JH. 2014. Memory recall and modifications by activating neurons with elevated CREB. Nat Neurosci 17: $65-72$.

Kitamoto T. 2001. Conditional modification of behavior in Drosophila by targeted expression of a temperature-sensitive shibire allele in defined neurons. J Neurogenet 16: 205-228.

Kitamura T, Pignatelli M, Suh J, Kohara K, Yoshiki A, Abe K, Tonegawa S. 2014. Island cells control temporal association memory. Science 343: 896-901. 
Koenig J, Linder AN, Leutgeb JK, Leutgeb S. 2011. The spatial periodicity of grid cells is not sustained during reduced $\theta$ oscillations. Science 332: $592-595$.

Kohara K, Pignatelli M, Rivest AJ, Jung HY, Kitamura T, Suh J, Frank D, Kajikawa K, Mise N, Obata Y, et al. 2014. Cell type-specific genetic and optogenetic tools reveal hippocampal CA2 circuits. Nat Neurosci 17: 269-279.

Kristiansen K, Kroeze WK, Willins DL, Gelber EI, Savage JE, Glennon RA, Roth BL. 2000. A highly conserved aspartic acid (Asp-155) anchors the terminal amine moiety of tryptamines and is involved in membrane targeting of the 5-HT(2A) serotonin receptor but does not participate in activation via a "salt-bridge disruption" mechanism. J Pharmacol Exp Ther 293: 735-746.

Kropff E, Treves A. 2008. The emergence of grid cells: intelligent design or just adaptation? Hippocampus 18: 1256-1269.

Langston RF, Ainge JA, Couey JJ, Canto CB, Bjerknes TL, Witter MP, Moser EI, Moser MB. 2010. Development of the spatial representation system in the rat. Science 328: $1576-1580$.

Lechner HAE, Lein ES, Callaway EM. 2002. A genetic method for selective and quickly reversible silencing of mammalian neurons. J Neurosci 22: $5287-5290$.

Lerchner W, Xiao C, Nashmi R, Slimko EM, van Trigt L, Lester HA, Anderson DJ. 2007. Reversible silencing of neuronal excitability in behaving mice by a genetically targeted, ivermectin-gated Cl-channel. Neuron 54: 35-49.

Lever C, Burton S, Jeewajee A, O'Keefe J, Burgess N. 2009. Boundary vector cells in the subiculum of the hippocampal formation. J Neurosci 29: 9771-9777.

Lewandowski M. 2002. Conditional control of gene expression in the mouse. Nat Rev Genet 2: 743-755.

Lin JY, Lin MZ, Steinbach P, Tsien RY. 2009. Characterization of engineered channelrhodopsin variants with improved properties and kinetics. Biophys J 96: 1803-1814.

Lin JY, Knutsen PM, Muller A, Kleinfeld D, Tsien RY. 2013. ReaChR: a red-shifted variant of channelrhodopsin enables deep transcranial optogenetic excitation. Nat Neurosci 16: 1499-1508.

Liu X, Ramirez S, Pang PT, Puryr CB, Govindarajan A, Deisseroth K, Tonegawa S. 2012. Optogenetic stimulation of a hippocampal engram activates fear memory recall. Nature 484: 381-385.

Magnus CJ, Lee PH, Atasoy D, Su HH, Looger LL, Sternson SM. 2011. Chemical and genetic engineering of selective ion channel-ligand interactions. Science 333: 1292-1296.

Mayford M, Bach ME, Huang YY, Wang L, Hawkins RD, Kandel ER. 1996. Control of memory formation through regulated expression of a CaMKII transgene. Science 274: 1678-1683.

McNaughton BL, Battaglia FP, Jensen O, Moser EI, Moser MB. 2006. Path integration and the neural basis of the 'cognitive map'. Nat Rev Neurosci 7: $663-678$.

Metzger D, Clifford J, Chiba H, Chambon P. 1995. Conditional site-specific recombination in mammalian cells using a ligand-dependent chimeric Cre recombinase. Proc Natl Acad Sci 92: 6991-6995.

Mizuseki K, Sirota A, Pastalkova E, Buzsaki G. 2009. $\theta$ Oscillations provide temporal windows for local circuit computation in the entorhinal-hippocampal loop. Neuron 64: 267-280.

Monaco JD, Abbott LF. 2011. Modular realignment of entorhinal grid cell activity as a basis for hippocampal remapping. JNeurosci 31: 9414-9425.

Nakashiba T, Young JZ, McHugh TJ, Buhl DL, Tonegawa S. 2008. Transgenic inhibition of synaptic transmission reveals role of CA3 output in hippocampal learning. Science 319: 1260-1264.

Neunuebel JP, Knierim JJ. 2014. CA3 retrieves coherent representations from degraded input: direct evidence for CA3 pattern completion and dentate gyrus pattern separation. Neuron 81: 416-427.

Neunuebel JP, Yoganarasimha D, Rao G, Knierim JJ. 2013. Conflicts between local and global spatial frameworks dissociate neural representations of the lateral and medial entorhinal cortex. J Neurosci 33: 9246-9258.

Nichols CD, Roth BL. 2009. Engineered G-protein coupled receptors are powerful tools to investigate biological processes and behaviors. Front Mol Neurosci 2: 16.

Nitabach MN, Blau J, Holmes TC. 2002. Electrical silencing of Drosophila pacemaker neurons stops the free-running circadian clock. Cell 109: $485-495$.

O'Keefe J, Burgess N. 1996. Geometric determinants of the place fields of hippocampal neurons. Nature 381: 425-428.

O'Keefe J, Dostrovsky J. 1971. The hippocampus as a spatial map. Preliminary evidence from unit activity in the freely-moving rat. Brain Res 34: $171-175$.

Ramirez S, Liu X, Lin PA, Suh J, Pignatelli M, Redondo RL, Ryan TJ, Tonegawa S. 2013. Creating a false memory in the hippocampus. Science 341: $387-391$.

Ranck JB. 1985. Head direction cells in the deep layer of dorsal presubiculum in freely moving rats. In Electrical activity of the archicortex (ed. Buzsaki G, Vanderwolf CH), pp. 217-220. Akademiai Kiado, Budapest.

Reijmers LG, Perkins BL, Matsuo N, Mayford M. 2007. Localization of a stable neural correlate of associative memory. Science 317: 1230-1233.

Rivas J, Gatztelu JM, Garcia-Austt E. 1996. Changes in hippocampal cell discharge patterns and $\theta$ rhythm spectral properties as a function of walking velocity in the guinea pig. Exp Brain Res 108: 113-118.

Rogan SC, Roth BL. 2011. Remote control of neuronal signaling. Pharmacol Rev 63: 291-315.

Rolls ET, Stringer SM, Elliot T. 2006. Entorhinal cortex grid cells can map to hippocampal place cells by competitive learning. Network 17: 447-465.

Rowland DC, Weible AP, Wickersham IR, Wu H, Mayford M, Witter MP, Kentros CG. 2013. Transgenically targeted rabies virus demonstrates a major monosynaptic projection from hippocampal area CA2 to medial entorhinal layer II neurons. J Neurosci 33: 14889-14898.

Ryding ADS, Sharp MGF, Mullins JJ. 2001. Conditional transgenic technologies. J Endocrinol 171: 1-14.

Samsonovich A, McNaughton BL. 1997. Path integration and cognitive mapping in a continuous attractor neural network model. J Neurosci 17: $5900-5920$.

Sargolini F, Fyhn M, Hafting T, McNaughton BL, Witter MP, Moser MB, Moser EI. 2006. Conjunctive representation of position, direction, and velocity in entorhinal cortex. Science 312: 758-762.

Sauer S. 1998. Inducible gene targeting in mice using the Cre/lox system. Methods 14: 381-392.

Savelli F, Knierim JJ. 2010. Hebbian analysis of the transformation of medial entorhinal grid cell inputs to hippocampal place fields. J Neurophysiol 103: 3167-3183.

Savelli F, Yoganarasimha D, Knierim JJ. 2008. Influence of boundary removal on the spatial representations of the medial entorhinal cortex. Hippocampus 18: 1270-1282.

Scoville WB, Milner B. 1957. Loss of recent memory after bilateral hippocampal lesions. J Neurol Neurosurg Psychiatry 20: 11-21.

Si S, Treves A. 2009. The role of competitive learning in the generation of DG fields from EC inputs. Cogn Neurodyn 3: 177-187.

Slimko EM, McKinney S, Anderson DJ, Davidson N, Lester HA. 2002. Selective electrical signaling of mammalian neurons in vitro by the use of invertebrate ligand-gated chloride channels. J Neurosci 22: $7373-7379$.

Solstad T, Moser EI, Einevoll GT. 2006. From grid cells to place cells: a mathematical model. Hippocampus 16: 1026-1031.

Solstad T, Boccara C, Kropff E, Moser MB, Moser E. 2008. Representation of geometric borders in the entorhinal cortex. Science 322: $1865-1868$

Soudais C, Laplace-Builhe C, Kissa K, Kremer EJ. 2001. Preferential transduction of neurons by canine adenovirus vectors and their efficient retrograde transport in vivo. FASEB J 15: 2283-2285.

Srinivasan S, Vaisse C, Conklin BR. 2003. Engineering the melanocortin-4 receptor to control G(s) signaling in vivo. Ann N Y Acad Sci 994: $225-232$.

Strader CD, Gaffney T, Sugg EE, Candelore MR, Keys R, Patchett AA, Dixon RA. 1991. Allele-specific activation of genetically engineered receptors. J Biol Chem 266: 5-8.

Tan EM, Yamaguchi Y, Horwitz GD, Gosgnach S, Lein ES, Goulding M, Albright TS, Callaway EM. 2006. Selective and quickly reversible inactivation of mammalian neurons in vivo using the Drosophila allatostatin receptor. Neuron 51: $157-170$.

Tan W, Janczewski WA, Yang P, Shao XM, Callaway EM, Feldman JL. 2008. Silencing preBotzinger complex somatostatin-expressing neurons induces persistent apnea in awake rat. Nat Neurosci 11: 538-540.

Taube JS, Muller RU, Ranck JB. 1990a. Head-direction cells recorded from the post-subiculum in freely moving rats. I. Description and quantitative analysis. J Neurosci 10: 420-435.

Taube JS, Muller RU, Ranck JB. 1990b. Head-direction cells recorded from the post-subiculum in freely moving rats. II. Effects of environmental manipulations. J Neurosci 10: 437-447.

Tervo D, Karpova AY. 2007. Rapidly inducible, genetically targeted inactivation of neural and synaptic activity in vivo. Curr Opin Neurobiol 17: $581-586$.

Tsodyks M. 1999. Attractor neural network models of spatial maps in hippocampus. Hippocampus 9: 481-489.

Walther W, Stein U. 2000. Viral vectors for gene transfer. Drugs 60: 249-271.

Wang KH, Majewska A, Schummers J, Farley B, Hu C, Sur M, Tonegawa S. 2006. In vivo two-photon imaging reveals a role of $A r c$ in enhancing orientation specificity in visual cortex. Cell 126: $389-402$.

Wang H, Yang H, Chivalila CS, Dawlaty MM, Cheng AW, Zhang F, Jaenisch R. 2013. One-step generation of mice carrying mutations in multiple genes by CRISPR/Cas-mediated genome engineering. Cell 153: $910-918$

Wehr M, Hostick U, Kyweriga M, Tan A, Weible AP, Wu H, Wu W, Callaway EM, Kentros CG. 2009. Transgenic silencing of neurons in the 
mammalian brain by expression of the allatostatin receptor (AlstR). J Neurophysiol 102: 2554-2562.

Weible AP, Schwarcz L, Wickersham IR, Deblander L, Wu H, Callaway EM, Seung HS, Kentros CG. 2010. Transgenic targeting of recombinant rabies virus reveals monosynaptic connectivity of specific neurons. J Neurosci 30: 16509-16513.

Welday AC, Shlifer IG, Bloom ML, Zhang K, Blair TD. 2011. Cosine directional tuning of $\theta$ cell burst frequencies: evidence for spatial coding by oscillatory interference. J Neurosci 31: 16157-16176.

Wickersham IR, Lyon DC, Barnard RJ, Mori T, Finke S, Conzelmann KK, Young JAT, Callaway EM. 2007. Monosynaptic restriction of transsynaptic tracing from single, genetically targeted neurons. Neuron 53: $639-647$.

Wietek J, Wiegert JS, Adeishvili N, Schneider F, Watanabe H, Tsunoda SP, Vogt A, Elstner M, Oertner TG, Hegemann P. 2014. Conversion of channelrhodopsin into a light-gated chloride channel. Science 344: $409-412$.

Wills TJ, Cacucci F, Burgess N, O'Keefe J. 2010. Development of the hippocampal cognitive map in preweanling rats. Science 328: $1573-1576$.

Wulff P, Arenkiel BR. 2012. Chemical genetics: receptor-ligand pairs for rapid manipulation of neuronal activity. Curr Opin Neurobiol 22: 54-60.

Wulff P, Goetz T, Leppa E, Linden AM, Renzi M, Swinny JD, Vekovischeva OY, Sieghart W, Somogyi P, Korpi ER, et al. 2007. From synapse to behavior: rapid modulation of defined neuronal types with engineered GABAA receptors. Nat Neurosci 10: 923-929.

Yang H, Wang H, Shivalila CS, Cheng AW, Shi L, Jaenisch R. 2013. One-step generation of mice carrying reporter and conditional alleles by CRISPR/ Cas-mediated genome engineering. Cell 154: 1370-1379.

Yizhar O, Fenno LE, Davidson TJ, Mogri M, Deisseroth K. 2011a. Optogenetics in neural systems. Neuron 71: 9-34.

Yizhar O, Fenno LE, Prigge M, Schneider F, Davidson TJ, O'Shea DJ, Sohal VS, Goshen I, Finkelstein J, Paz JT, et al. 2011b. Neocortical excitation/inhibition balance in information processing and social dysfunction. Nature 477: 171-178.

Yu CR, Power J, Barnea G, O'Donnell S, Brown HEV, Osborne J, Axel R, Gogos JA. 2004. Spontaneous neural activity is required for the establishment and maintenance of the olfactory sensory map. Neuron 42: $553-566$.

Zemelman BV, Nesnas N, Lee GA, Miesenbock G. 2003. Photochemical gating of heterologous ion channels: remote control over genetically designated populations of neurons. Proc Natl Acad Sci 100: 13521357.

Zhang F, Wang LP, Brauner M, Liewald JF, Kay K, Watzke N, Wood PG, Bamberg E, Nagel G, Gottschalk A, et al. 2007. Multimodal fast optical interrogation of neural circuitry. Nature 446: 633-639.

Zhang F, Prigge M, Beyriere F, Tsunoda SP, Mattis J, Yizhar O, Hegemann P, Deisseroth K. 2008. Red-shifted optogenetic excitation: a tool for fast neural control derived from Volvox carteri. Nat Neurosci 11: 631-633.

Zhang F, Gradinaru V, Adamantidis AR, Durand R, Airan RD, de Lecea L, Deisseroth K. 2010. Optogenetic interrogation of neural circuits: technology for probing mammalian brain structures. Nat Protoc 5: $439-456$.

Zhang F, Vierock J, Yizhar O, Fenno LE, Tsunoda S, Kianianmomeni A, Prigge M, Berndt A, Cushman J, Polle J, et al. 2011. The microbial opsin family of optogenetic tools. Cell 147: 1446-1457.

Zhang SJ, Ye J, Miao C, Tsao A, Cerniauskas I, Ledergerber D, Moser MB, Moser EI. 2013. Optogenetic dissection of entorhinal-hippocampal functional connectivity. Science 340: 1232627.

Zhu H, Pleil KE, Urban DJ, Moy SS, Kash TL, Roth BL. 2014. Chemogenetic inactivation of ventral hippocampal glutamatergic neurons disrupts consolidation of contextual fear memory. Neuropsychopharmacology 39: $1880-1892$.

Received June 18, 2014; accepted in revised form August 2, 2014. 


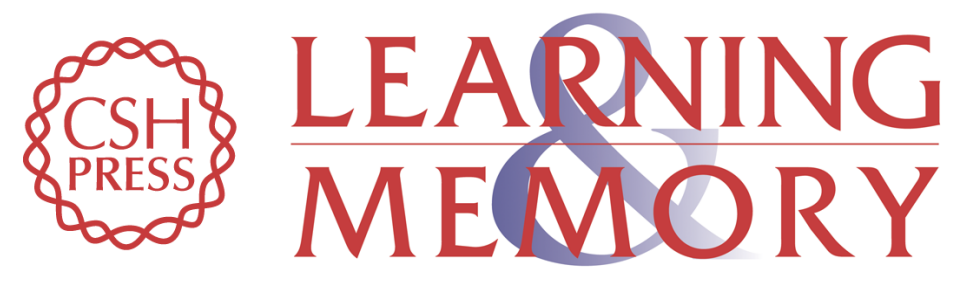

\section{Beyond the bolus: transgenic tools for investigating the neurophysiology of learning and memory}

Christine Lykken and Clifford G. Kentros

Learn. Mem. 2014, 21:

Access the most recent version at doi:10.1101//m.036152.114

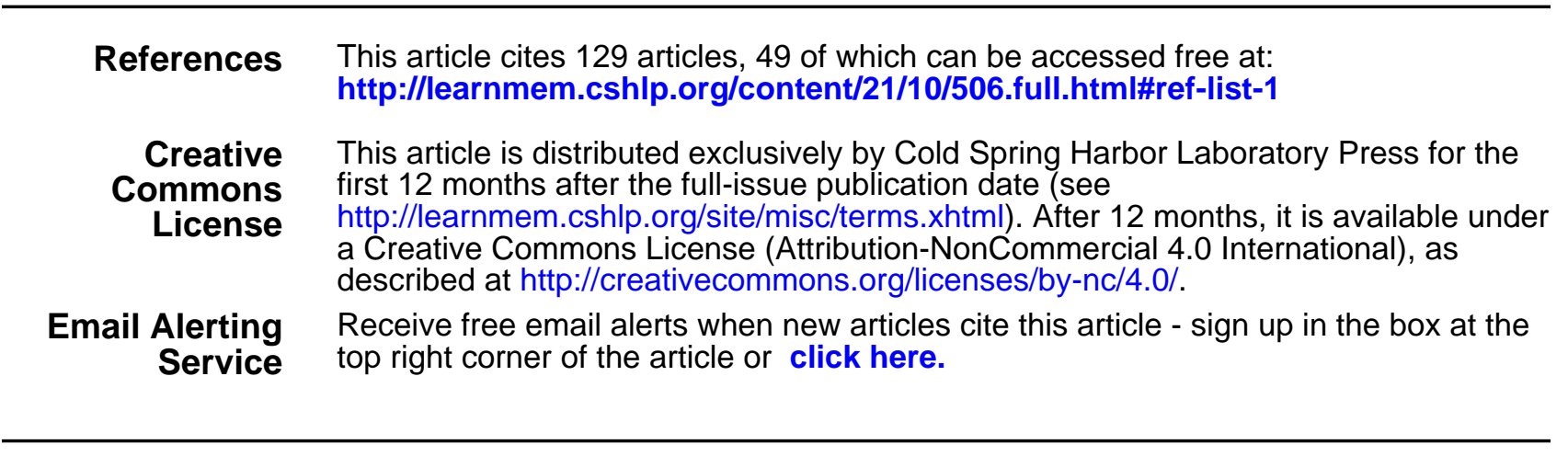

